\title{
INTEGRASI PENDIDIKAN BERKARAKTER DALAM PEMBELAJARAN BAHASA INGGRIS
}

\author{
Rr. Astri Indriana Octavita ${ }^{1}$, Ria Saraswati ${ }^{2}$ \\ 1,2Program Studi Pendidikan Bahasa Inggris, Fakultas Bahasa dan Seni Universitas Indraprasta PGRI \\ Jl. Nangka 58 Tanjung Barat, Jakarta Selatan, Indonesia \\ Email:1'mrs.astriindriana@gmail.com \\ 2riri.saraswati21@gmail.com
}

\begin{abstract}
This study is aimed to integrated between character education and teaching of English Language for kindergarten teachers in LPI NUR HIKMAH Kampung Sawah. The Urgent of the theme as an expression that shows to the teachers about how to the implementation of teaching the English Language based on character education. English as an International Language needs to be developed in school learning process, but conventional language learning tends to be centered on the teacher and ignore the existence of learners. Learning English is good not only in developing cognitive abilities but also instill the value of the learners. The values of character education inEnglish subjects are friendly, caring, social, curiosity, democratic, independent, hard work, discipline, and love to read. The values of character education can be embedded in learners with learning English contextually. Constructivism concepts, inquiry, and questioning, are relevant to the values of independence, hard work, and curiosity. Meanwhile, the values of friendship, social care, discipline, love to read, and democracy can be implanted with the concept of modeling reflection and authentic assessment. The values of learning English based on character education are making students construct knowledge of English actively, gain knowledge through experience, discuss in groups and working in groups. In addition, the teacher presents the model as an example of learning, makes the reflection at the end of the meeting, and makes the process of assessment. Therefore, the resulting output is the ability of teachers to implement character education in learning English so that learning English does not tend to be centered on teachers and ignore the existence of learners. The values of character education in English subject are friendly, caring, social, curiosity, democratic, independent, hard work, discipline, and love to read.
\end{abstract}

\section{Keywords: Learning English, Integration, Character Education, Contextual}

\begin{abstract}
Abstrak. Tujuan diadakannya pengabdian masyarakat ini adalah memberikan pelatihan penerapan pendidikan berkarakter dalam pembelajaran Bahasa Inggris bagi guru TK LPI NUR HIKMAH Kampung Sawah. Bahasa Inggris sebagai Bahasa International, memang perlu dikembangkan dalam pembelajaran disekolah akan tetapi pembelajaran bahasa yang konvensional cenderung berpusat pada guru dan mengabaikan keberadaan peserta didik. Pembelajaran Bahasa Inggris yang baik tidak hanya mengembangkan kemampuan kognitif namun juga menanamkan nilai pada diri peserta didik. Nilai-nilai pendidikan karakter pada mata pelajaran Bahasa Inggris adalah bersahabat, peduli, soial, rasa ingin tahu, demokratis, mandiri, kerja keras, disiplin, dan senang membaca. Nilai-nilai pendidikan karakter dapat ditanamkan pada diri peserta didik dengan pembelajaran Bahasa Inggris secara kontekstual. Konsep contructivism, inquiry, dan questioning relevan dengan nilai-nilai mandiri, kerja keras, dan rasa ingin tahu. Sedangkan, nilainilai bersahabat, peduli sosial, disiplin, gemar membaca, dan demokratis dapat ditanamkan dengan konsep learning community modeling reflection dan authentic assessment. Prosedur pembelajaran
\end{abstract}


Bahasa Inggris yang berkarakter adalah membuat peserta didik mengkonstruksi pengetahuan Bahasa Inggris secara aktif, memperoleh pengetahuan melalui pengalaman, berdiskusi dalam kelompok, dan bekerja dalam kelompok. Di samping itu, guru menghadirkan model sebagai contoh pembelajaran, melakukan refleksi di akhir pertemuan, dan melakukan proses penilaian. Oleh karena itu, luaran yang dihasilkan adalah kemampuan guru dalam menerapkan pendidikan berkarakter di dalam pembelajaran Bahasa Inggris sehingga pembelajaran Bahasa Inggris tidak cenderung berpusat pada guru dan mengabaikan peserta didik.Nilai-nilai pendidikan karakter pada mata pelajaran Bahasa Inggris adalah bersahabat, peduli, sosial, rasa ingin tahu, demokratis, mandiri, kerja keras, disiplin, dan senang membaca.

\section{Kata Kunci: Pembelajaran Bahasa Inggris, Integrasi, Pendidikan Karakter, Kontekstual}

\section{PENDAHULUAN}

Lembaga Pendidikan Islam (LPI) Nur Hikmah adalah sekolah yang mengedepankan akhlaq (budi pekerti) namun tidak mengenyampingkan kemampuan kognisi. Didirikan pada tahun 1996 di daerah Kampung Sawah, banguan awal sekolah adalah SDIT dan TKA yang diresmikan oleh wakil menteri agama dan bapak Yusuf Thalib S.H. serta pejabat setempat dan para penyumbang. Sekolah tersebut terdiri dari 12 lokal, 4 lokal asrama guru-guru, mushola, dan lain-lainnya. Sekarang murid SDIT dari kelas 1 sampai kelas 6 berjumlah 226 anak, murid TKS sejumlah 110 anak. Sekolah ini mempunyai misi mengupayakan terpadunya aspek pengetahuan dan ketrampilan dengan sikap yang baik dan Islami, sehingga terbentuk generasi berakhlaqul karimah, mandiri dan berprestasi akademis optimal. Kurikulum sekolah ini adalah gabungan dari kurikulum Pendidikan Nasional, Departemen Agama dan pesantren. Perpaduan kurikulum ini dimasksudkan untuk mewujudkan siswa yang cerdas secara intelektual, emosional, dan spiritual sehingga memunculkan keseimbangan dalam diri mereka. Perbaduan kurikulum yang bertujuan mewujudkan siswa yang cerdas secara intelektual, emosional, dan spiritual dapat menjadi alasan utama kenapa LPI Nur Hikmah dijadikan mitra kegiatan pengabdian masyarakat semester ini. Selain itu, dipilihnya LPI Nur Hikmah adalah karena sekolah ini mengedepankan akhlaq namun tidak mengenyampingkan kemampuan kognisi. Dengan mengintegasikan nilai-nilai karakter dalam proses belajar mengajar, para siswa diharapkan tidak hanya memiliki kemampuan kognitif, tetapi mereka mampu menerapkan semua nilai yang terkandung dalam pendidikan karakter baik dalam kehidupan di sekolah maupun di masyarakat.

Bahasa Inggris sebagai Bahasa international, memang perlu dikembangkan dalam pembelajaran disekolah akan tetapi pembelajaran Bahasa Inggris yang konvensional cenderung berpusat pada guru dan mengabaikan keberadaan peserta didik. Pembelajaran bahasa Inggris yang baik tidak hanya mengembangkan kemampuan kognitif namun juga menanamkan nilai pada diri peserta didik. Nilai-nilai pendidikan karakter bangsa pada mata pelajaran bahasa Inggris adalah bersahabat/komunikatif, peduli sosial, rasa ingin tahu, demokratis, mandiri, kerja keras, disiplin, dan senang membaca. Nilai-nilai pendidikan karakter bangsa dapat ditanamkan pada diri peserta didik dengan pembelajaran bahasa Inggris secara kontekstual. Konsep constructivism, inquiry, dan questioning relevan dengan nilai-nilai mandiri, kerja, dan rasa ingin tahu. Sedangkan, nilai-nilai bersahabat/ komunikatif, peduli sosial, disiplin, gemar 
membaca, dan demokratis dapat ditanamkan dengan konsep learning community, modeling, reflection, dan authentic assessment. Prosedur pembelajaran bahasa Inggris yang berkarakter adalah membuat peserta didik mengkonstruksi pengetahuan bahasa Inggris secara aktif, memperoleh pengetahuan melalui pengalaman, berdiskusi dalam kelompok, dan bekerja dalam kelompok. Di samping itu, guru menghadirkan model sebagai contoh pembelajaran, melakukan refleksi di akhir pertemuan, dan melakukan penilaian proses.

Nilai karakter yang dapat diitegrasikan dalam mata pelajaran bahasa Inggris terdiri dari beberapa nilai karakter pokok atau utama. Ketentuan yang berkenaan dengan nilai karakter pokok atau utama itu bukan berarti membatasi pengenalan, pengembangan, dan pembudayaan nilai karakter yang lain. Artinya, nilai karakter yang lain, sepanjang memungkinkan diitegrasikan dalam pembelajaran, juga dianjurkan untuk dikenalkan, dikembangkan, dan dibudayakan dalam kehidupan nyata peserta didik. Nilai karakter pokok, dalam hal ini, ialah nilai karakter yang dijadikan pangkal tolak pengembangan nilai karakter yang lain. Melalui penanaman, pengembangan, dan pembudayaan nilai karakter pokok ini diharapkan nilai karakter yang lain dapat dikembangkan pula. Nilai karakter utama ialah nilai karakter yang diprioritaskan untuk ditanamkan, dikembangkan, dan dibudayakan bagi dan oleh peserta didik. Beberapa nilai karakter utama juga disebutkan dalam nilai karakter pokok karena nilai karakter itu merupakan dasar atau pangkal tolak pengenalan, pengembangan, dan pembudayaan nilai karakter yang lain.

Satu hal yang perlu disadari ialah tidak ada nilai karakter kehidupan manusia yang berdiri sendiri, terpisah satu dengan yang lain. Ni- lai karakter yang satu dan nilai karakter yang lain senantiasa saling bersinggungan, tumpang tindih, dan atau terkait; bahkan nilai karakter yang satu kadang merupakan prasyarat bagi nilai karakter yang lain; nilai karakter yang satu kadang juga merupakan manifestasi atau perwujudan dari nilai karakter yang lain.

Tujuan kegiatan pengabdian masyarakat ini adalah memberikan pelatihan bagi guru TKLPI Nur Hikmah mengimplementasikan pendidikan karakter pada kegiatan pembelajaran Bahasa Inggris dan untuk memberikan informasi tentang implementasi pendidikan karakter pada kegiatan pembelajaran Bahasa Inggris yang telah dilaksanakan oleh guru. Kegiatan pengabdian masyarakat ini diharapkan dapat memberikan pengetahuan mengenai implementasi pendidikan berkarakter dalam pembelajaran Bahasa Inggris.

\section{METODE PELAKSANAAN}

Pemilihan mitra dalam kegiatan pengabdian masyarakat ini adalah berdasarkan kebutuhan para guru dalam mengimplementasikan pendidikan karakter pada kegiatan pembelajaran Bahasa Inggris.

Penginsersian muatan karakter dapat dilakukan melalui 3 tahap: persiapan, implementasi, dan evaluasi. Dari ketiga tahap ini, secara logika pengembangan materi dilakukan pada tahap persiapan.Karena sifatnya muatan, pada pelaksanaanya, pengembangan materi ini bahasa Inggris sebaiknya dilakukan terlebih dahulu, baru dilanjutkan dengan penyisipan materi karakter dalam materi inti ini.Tetapi, harus diupayakan agar materi inti dan materi karakter yang dimuatkan menyatu dan menjadi satu bagian materi yang selaras dan koheren. Langkah sederhananya adalah sebagai berikut. 
1. Tentukan standar kompetensi (SK), kompetensi dasar (KD) dan tujuan pembelajaran yang ingin dicapai.

2. Tentukan aspek nilai-nilai/karakter (dari 18 karakter) yang dapat disisipkan dalam pencapaian tujuan pembelajaran tersebut

3. Pilih atau kembangkan materi bahasa Inggris (inti) yang akan digunakan untuk mencapai $\mathrm{KD} /$ tujuan pembelajaran yang telah direncanakan; materi bisa berbasis cerita, berupa gambar, video, kartun, dan sebagainya.

4. Kembangkan materi bahasa Inggris tersebut sehingga mengakomodasi pengembangan nilai/karakter yang telah ditentukan

5. Pengembangan materi ini harus mengakomodasi prinsip-prinsip karakteristik siswa yang ingin dicapai.

6. Setelah materi bermuatan karakter berhasil dikembangkan, perkirakan langkahlangkah pembelajaran yang menarik dan inovatif dengan mengacu pada prinsipprinsip pembelajaran bahasa Inggris. Hal ini penting karena materi harus bisa digunakan dan sejalan dengan langkahlangkah pembelajaran. Lanjutkan dengan aspek-aspek rencana pelaksanaan pembelajaran (RPP) lainnya.

Jadwal pelaksanaan kegiatan dimulai bulan Agustus sampai Pebruari. Adapun tahapan kegiatan yang dilaksanakan sebagai berikut

1. Tahap Persiapan, kegiatan yang dilakuakan diskusi tim, mencari tinjauan pustaka, observasi tempat pelaksanaan, pengajuan proposal

2. Tahapa Aplikasi, kegiatan yang dilakukan persiapan materi, presentasi dan pelatihan

3. Tahap Laporan

\section{HASIL DAN PEMBAHASAN}

Pendidikan karakter bukan hal yang baru dalam sistem pendidikan nasionalIndonesia. Pada saat ini, setidak-tidaknya sudah ada dua mata pelajaran yang diberikan untuk membina akhlak dan budi pekerti peserta didik, yaitu Pendidikan Agama dan PKn. Namun demikian, pembinaan watak melalui kedua mata pelajaran tersebut belum membuahkan hasil yang memuaskan karena beberapa hal. Pertama, kedua mata pelajaran tersebut cenderung baru membekali pengetahuan mengenai nilainilai melalui materi/substansi mata pelajaran. Kedua, kegiatan pembelajaran pada kedua mata pelajaran tersebut pada umumnya belum secara memadai mendorong terinternalisasinya nilainilai oleh masing-masing siswa sehingga siswa berperilaku dengan karakter yang tangguh. Ketiga, menggantungkan pembentukan watak siswa melalui kedua mata pelajaran itu saja tidak cukup.Pengembangan karakter peserta didik perlu melibatkan lebih banyak lagi mata pelajaran, bahkan semua mata pelajaran.

Pendidikan karakter seharusnya membawa peserta didik ke pengenalan nilai secara kognitif, penghayatan nilai secara afektif, dan akhirnya ke pengamalan nilai secara nyata. Inilah rancangan pendidikan karakter (moral) yang oleh Thomas Lickona disebut moral knowing, moral feeling, dan moral action (Lickona, 1991: 51). Karena itulah, semua mapel yang dipelajari oleh peserta didik harus bermuatan pendidikan karakter yang bisa membawanya menjadi manusia yang berkarakter seperti yang ditegaskan oleh Lickona tersebut. Karena itulah, semua mapel yang dipelajari oleh peserta didik di sekolah harus bermuatan pendidikan karakter yang bisa membawanya menjadi manusia yang berkarakter. Salah satu- 
nya penerapan pendidikan karakter adalah dalam pembelajaran Bahasa Inggris.

Dengan mengintegasikan nilai-nilai karakter dalam proses belajar mengajar, para siswa diharapkan tidak hanya memiliki kemampuan kognitif, tetapi mereka mampu menerapkan semua nilai yang terkandung dalam pendidikan karakter baik dalam kehidupan di sekolah maupun di masyarakat. Pada prinsipnya pengembangan nilai-nilai karakter tidak dimuat secara khusus dalam sebuah mata pelajaran tertentu, namun ini disisipkan ke dalam setiap mata pelajaran di sekolah, pengembangan diri siswa, dan budaya sekolah sehingga para siswa berkembang menjadi pribadi yang berintelektualitas dan berkarakter.Oleh sebab itu, para guru dan sekolah perlu mengintegrasikan nilai-nilai karakter ke dalam kurikulum, silabus, dan rencana pelaksanaan pembelajaran (RPP) yang mereka pakai di sekolah.Penyisipan nilai-nilai karakter diharapkan terjadi pada semua mata pelajaran, seperti misalnya bahasa Inggris, matematika, sejarah, geografi, dan lain-lain. Dalam mengembangkan pengajaran bahasa Inggris bermuatan nilai karakter, guru memiliki peran penting karena mereka harus menentukan strategi yang efektif dalam mengembangkan karakter pebelajar dengan tanpa mengurangi kualitas konten akademik mata pelajaran tersebut.

Hasil menunjukkan bahwa guru telah mengimplementasikan 10 nilai karakter pada kegiatan pembelajaran Bahasa Inggris. Implementasi nilai-nilai karakter tersebut adalah (1) religiusitas dengan cara berdoa sebelum dan sesudah pembelajaran; (2) toleransi dengan cara memberikan pelayanan yang sama dan membagi kelompok siswa dengan adil; (3) kedisiplinan dengan melaksanakan prosedur pembelajaran dan menggunakan waktu secara efektif; (4) kerja keras dengan cara memberikan substansi pembelajaran yang membiasakan siswa bekerja keras dan meminta siswa berusaha keras untuk mencari informasi dari berbagai sumber; (5) kemandirian dengan memberikan tugas pada siswa untuk menumbuhkan rasa percaya diri; (6) demokrasi dengan melaksanakan pembelajaran yang interaktif dan melibatkan semua siswa secara aktif selama pembelajaran; (7) kekomunikatifan dengan cara mengatur kelas, menerapkan pembelajaran dialogis, mendengarkan keluhankeluhan siswa, memelihara komunikasi yang baik dengan siswa, dan menyajikan tugas secara lisan atau tertulis; (8) kedamaian dengan menciptakan suasana kelas yang damai dan kekerabatan di kelas yang penuh kasih sayang; (9) kegemaran membaca dengan memotivasi siswa untuk menggunakan referensi; (10) kekreatifan dengan cara pemberian tugas-tugas yang memacu siswa memunculkan karyakarya baru.

Sehingga, luaran yang ditemukan dari pelatihan di LPI Nur Hikmah pendidikan karakter sudah dimasukkan dalam pelajaran bahasa Inggris di tingkat satuan pendidikan sekolah dasar (SD). Secara khusus, pelatihan ini membahas tentang perencanaan pendidikan karakter melalui rencana pelaksanaan pembelajaran (RPP) dan implementasi RPP dalam pembelajaran bahasa Inggris yang menyisipkan pendidikan karakter.Pelatihan ini diharapkan mampu memberi manfaat sebagai referensi bagi para guru SD dalam mengembangkan rencana pelaksanaan pembelajaran (RPP) dan melaksanakan pembelajaran bahasa Inggris dengan memasukkan nilai pendidikan karakter pada tingkat pendidikan dasar (SD).

Adapun sesi-sesi dokumentasi kegiatan pelatihan ini adalah sebagai berikut: 


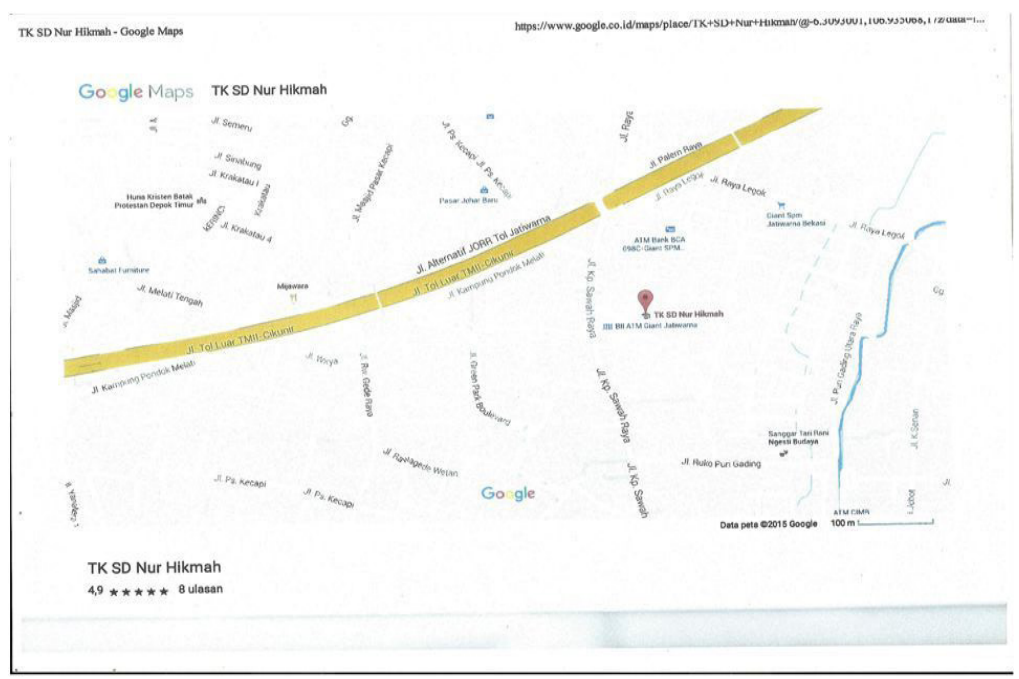

Gambar 1. Peta Wilayah Lokasi Pelatihan Guru-Guru TK LPI Nur Hikmah Kampung Sawah Bekasi Selatan
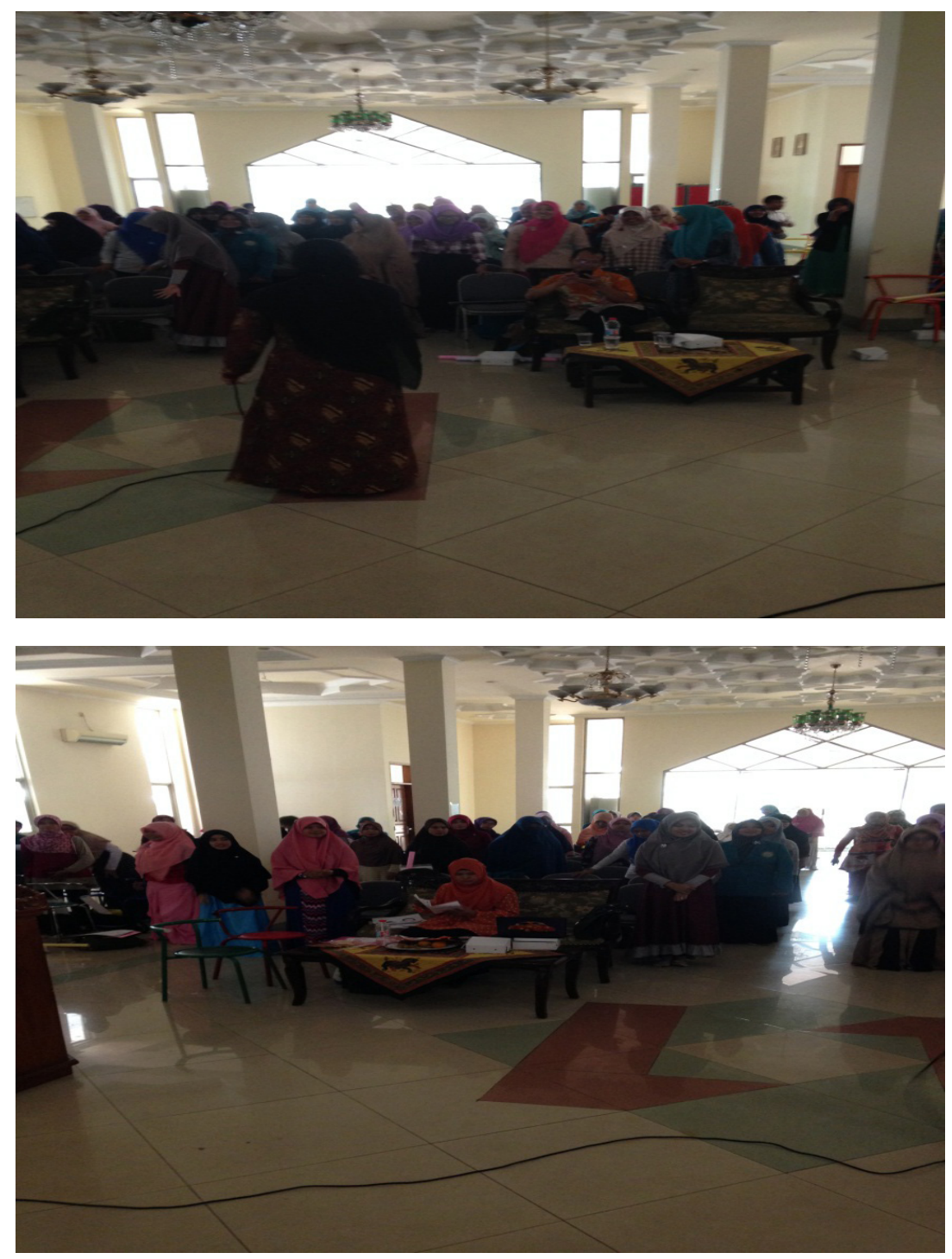

Gambar 2. Pelaksanaan Pelatihan di LPI Nur Hikmah Kampung Sawah 


\section{SIMPULAN DAN SARAN}

\section{Simpulan}

Pendidikan karakter di sekolah sebaiknya dilakukan dengan tidak melalui pembentukan mata pelajaran baru, tetapi melalui insersi ke dalam pembelajaran dan kegiatan ekstrakurikuler di sekolah. Sesuai dengan saran Puskur (2010), insersi pendidikan karakter ini dapat dilakukan pada tahap persiapan, pelaksanaan, dan evalusi. Khusus terkait dengan pengembangan materi Bahasa Inggris bermuatan karakter, prakteknya dilakukan pada tahap persiapan, di mana pertama guru harus lebih dahulu menentukan SK, KD, tujuan pembelajaran, serta nilai-nilai atau karakter yang mungkin dikembangkan didasarkan atas $\mathrm{SK} / \mathrm{KD}$ dan tujuan pembelajaran. Di sini guru harus mencari celah di mana materi karakter dapat dimuatkan dalam materi inti sehingga materi Bahasa Inggris bermuatan karakter yang dikembangkan dapat terlihat sebagai sebuah keutuhan yang selaras.

\section{Saran}

Pendidikan berkarakter melalui pembelajaran bahasa Inggris bukan hanya bagi guruguru Bahasa Inggris saja, tetapi juga dapat berlaku bagi peserta didik berbagai jurusan yang ingin belajar Bahasa Inggris secara mandiri. Dengan pengembangan pengajaran bahasa Inggris bermuatan nilai karakter, guru harus berperan pentingdalam menentukan strategi yang efektif dalam mengembangkan karakter pembelajar dengan tanpa mengurangi kualitas konten akademik mata pelajaran tersebut. Dengan mengintegasikan nilai-nilai karakter dalam proses belajar mengajar, para siswa diharapkan tidak hanya memiliki kemampuan kognitif, tetapi mereka mampu menerapkan semua nilai yang terkandung dalam pendidikan karakter baik dalam kehidupan di sekolah maupun di masyarakat

\section{UCAPAN TERIMA KASIH}

Dengan memanjatkan puji syukur kehadirat Allah SWT yang telah melimpahkan rahmat dan karunia-Nya kepada penulis, sehingga dapat menyelesaikan laporan kegiatan pengabdian masyarakat tepat pada waktunya.

Pada dasarnya, kegiatan pengabdian kepada masyarakat dengan judul "Integrasi Pendidikan Berkarakter Dalam Pembelajaran Bahasa Inggris" ini tidak akan berhasil tanpa peran, bantuan dan dukungan dari berbagai pihak. Oleh karena itu, pada kesempatan ini tim pelaksana ingin mengucapkan terima kasih kepada:

1. Bapak Prof. Dr. H Sumaryoto selaku Rektor Universitas Indraprasta PGRI Jakarta.

2. Bapak Drs. H. Ahmad Sjamsuri, M.M. selaku Kepala LPPM Universitas Indraprasta PGRI

3. Bapak Munzir, M.M.,M.Pd selaku Kepala Pusat Pengabdian Masyarakat LPPM Universitas Indraprasta PGRI Jakarta

4. Bapak Dr. Supeno, M.Hum selaku Dekan FBS Universitas Indraprasta PGRI Jakarta

5. Ibu Ira Miranti, M.Hum selaku KAPRODI Pendidikan Bahasa Inggris Universitas Indraprasta PGRI Jakarta

6. Bapak Saminto, S.Sos.,MM. selaku Wakil Direktur LPI Nur Hikmah Kampung Sawah Bekasi Selatan

7. Guru - Guru TK LPI Nur Hikmah Kampung Sawah Bekasi Selatan

\section{DAFTAR PUSTAKA}

Cameron, L.Teaching Languages to Young Learners. Cambridge: Cambridge University Press.

Dewi, D. N. D. R. 2012.Designing Character Building Based Syllabus and Teaching Manual for Teaching English to Young 
Learners. Tesis takterpublikasi. Singaraja: Program Pascasarjana Undiksha.

Harmer, J. 2007.The Practice of English Language Teaching, 4th Edition. Essex: Pearson.

Kesuma, D., Triatna, C., dan Permana, J. 2011.

Pendidikan Karakter: Kajian Teori dan Praktik di Sekolah. Bandung: Remaja Rosdakarya.

Lickona,T. 2004. Character Matters: How to Help Our Children Develop
Good Judgment, Integrity, and Other Essential Virtues. New York: Touchstone.

Puskur. 2010. Bahan Pelatihan Penguatan Metodologi Pembelajaran Berdasarkan Nilai-Nilai Budaya untuk Membentuk Daya Saing danKarakter Bangsa:Pengembangan Pendidikan Budaya dan Karakter Bangsa. Jakarta: Puskur,Badan Penelitian dan Pengembangan, Kementerian Pendidikan Nasional. 